\title{
Historical encounters: Aboriginal testimony and colonial forms of commemoration
}

\author{
Maria Nugent
}

The figure of the Aboriginal eyewitness appears from time to time in accounts about Captain Cook at Botany Bay, and in discussions of how the history of Captain Cook at Botany Bay has been publicly remembered and represented. In each appearance, the eyewitness is deployed to contribute to some historical or memorial project. The evidence provided, apparently, by a named or unnamed Indigenous 'eyewitness' is called forth by colonial and post-colonial historians, writers, politicians, remembrancers and others. They do so to authenticate the location of a monument, to provide the 'other' side of the story of an historical event, to settle a controversy over the interpretation of the past in the present, or to make a critical point about the value or otherwise of Aboriginal knowledge in Australian history and memory.

In this paper, I follow the fortunes of some Aboriginal eyewitnesses at Botany Bay as they intermittently appear in the archive in order to raise questions about their changing uses and meanings in nineteenth and twentieth century forms and practices of history-making. Tracking these Aboriginal figures provides an avenue into a broader project aimed at gaining an understanding of Aboriginal and non-Aboriginal people's forms of history-making in the post- 1770 period and the integral relationship between the two. In this respect, I am especially interested in what happens to the figure of the Aboriginal eyewitness as it is 'exchanged' between different contexts of social memory.

\section{Enter the 'blackfellow, hoary with age'}

Chris Healy, in his study of social memory of Captain Cook, tells his readers that the location for a brass plaque at Botany Bay, commemorating Cook's and Banks' sojourn there, erected by the Philosophical Society of Australasia in 1822, might have been determined with the aid of information provided by an old local Aboriginal man who had witnessed the past that is memorialised. Wondering how the men of the Philosophical Society knew that the 'this spot' referred to on their plaque was 'the spot' that had once seen Cook and Banks 'in the pursuit of knowledge', Healy points to a clue contained in a speech made by Sir Joseph Carruthers in 1899, decades after the plaque's installation, which noted that:

There can be no reasonable doubt that this is the actual scene of Cook's landing, for we have the testimony of two old and respected colonists - Mr Alexander Berry and Dr Douglas [sic] - that in the early part of the century a blackfellow, 
hoary with age, who had actually witnessed the landing, identified to them this spot as the landing place. ${ }^{1}$

Sir Joseph Carruthers made his reference to the 'black fellow, hoary with age', who had apparently witnessed the arrival of Captain Cook, in a speech that he gave in 1899 at the ceremony to mark the dedication of 'Captain Cook's landing place' as a public reserve. ${ }^{2}$ For this titbit, Carruthers was drawing on an earlier speech, made at the same place, 35 years earlier. In 1863, Dr Douglass, one of the original members of the Philosophical Society, attended a reunion at Kurnell to honour Captain Cook. He explained to his small audience that a member of the Society, Sir Thomas Brisbane, had suggested 'the desirability of ascertaining the precise spot where Captain Cook landed, and directed that inquiries should be made amongst the natives of Botany Bay, if any of them saw the great captain arrive'. ' At length', according to Dr Douglass' recollection, 'an old black man was found whose hair was white from age, who said he had seen the big ship come in and the boats land, and could show the precise spot [where Cook landed]'.

Thus by the time Healy uncovers it in his researches, and incorporates it into his discussion of the 'white' social memory of Captain Cook, the reference to the 'blackfellow, hoary with age', is already many decades old, and second, if not third, hand. Chris Healy joined a conversation that had been in train for some time, at least intermittently. By picking up this particular thread of the conversation, and weaving it into his late twentieth-century critical study of social memory about Captain Cook, Healy introduced to a new audience this little-known aspect of the inscription plate's story. Perhaps more importantly, he enacted yet another exchange whereby this 'trace' of Aboriginal testimony about the deeds of 'white' men entered a new context of public memory, in which its meaning was interpreted anew.

For Healy, the value of this particular 'trace' was that it 'hints at the links between European social memory and indigenous knowledge'. ${ }^{5}$ His discussion of the archival fragment suggests that the link between European social memory and Indigenous knowledge is weighted heavily in favour of the former. He makes the searing observation that the Philosophical Society's inscription plate, while (apparently) dependent upon local Indigenous knowledge, made no reference at all to the presence of Indigenous people, before, during or after the arrival of Captain Cook. 'What makes this story tragic', Healy writes, 'is the simultaneous use of Aboriginal knowledge and disavowal of Aboriginal presence'. He continues:

The memories of an Aboriginal eyewitness were used by the Philosophical Society to memorialise a European discovery which they claimed as initiating history on a silent continent. Imagine the other conversations which could have taken place in relation to those rocks on Botany Bay. It seems that Mr Berry and Dr Douglas [sic] refused an opportunity for dialogue and a chance of translating social memory between cultures. Instead they cast deft and vital memory as brass dogma. ${ }^{6}$

1. Cited in Healy 1997: 22. For the original speech, see Carruthers 1899.

2. Carruthers 1899: 34-35.

3. Sydney Morning Herald, 18 May 1863, cited in Bertie 1924: 242.

4. Sydney Morning Herald, 18 May 1863, cited in Bertie 1924: 242.

5. Healy 1997: 22. 
This is a damning indictment of the members of the Philosophical Society in terms of their treatment of the local Aboriginal man's 'deft and vital memory', and of their failure to produce social memory or history of a different kind, a more dialogical kind than their monumental approach appears to have allowed.

Healy is certainly not alone in identifying and bemoaning the ways in which colonial monuments, and the monumental forms of history out of which they emerge, have served to block from view Aboriginal presence in place, before and after colonisation. ${ }^{7}$ There is little doubt that colonial monuments have made heroes out of 'voyagers', 'founders' and 'pioneers', and through them perpetuated myths about the origins of the white nation or how the country was 'settled', eclipsing in the process the 'other side of the story'. This is clearly reflected in the inscription on the brass plaque on the cliff face at Botany Bay, which names Cook and Banks as discoverers of these shores; puts them in company with heroes from other times ('the Columbus and Mæcenas of their time'); and is silent on the matter of who was in possession of 'this spot' when they arrived.

In his critical treatment of this tantalising trace of an Aboriginal man's testimony, which had been sought out in the context of public commemoration of the European past in Australia, Healy suggests that the ultimate realisation of the memorial project, which occurred when the inscription plate was finally hammered into the cliff face at Point Sutherland in March 1822, usurped the ephemeral exchange that had reportedly taken place between the local blackfellow and members of the Philosophical Society. Moreover, the very fact of the plaque's presence, with its honouring of the other's history, Healy argues, constitutes a denial of Aboriginal presence in the place, both past and present.

But is this necessarily so? Does this physical form of historical remembrance completely overshadow histories of Aboriginal presence in the place? Does it block from view instances of other, more ephemeral forms of exchanges between blacks and whites in the context of historical remembrance? I am interested in conceptualising the relationship between the colonial monument and the reported testimony of a local Aboriginal man in a slightly different way. Klaus Neumann ${ }^{8}$ makes a distinction between approaches in critical memory studies that 'read' the physical form of a monument as though it were a 'text' and those that focus instead, or additionally, on what he calls 'contexts of public memory', both past and present. His study is a series of detailed investigations into local memorial projects addressing the Nazi past in Germany. In his careful examination of a wide range of physical and public memorial sites, Neumann is 'particularly concerned with the discursive contexts that are not apparent to the passing visitor'. These 'discursive contexts' constitute the local memorial's own history, which are usually not obviously reflected in its form. 'Some of these histories', notes Neumann, 'are complex and contradictory. They often stretch over many years, but rarely leave easily discernible traces. ${ }^{\prime 9}$ They are aspects of a memorial most easily forgotten or overlooked.

6. Healy 1997: 23.

7. See for instance, Griffiths 1987: 22; Bulbeck 1991; Scates and Frances 1989.

8. Neumann 2000: Introduction.

9. Neumann 2000: 2. 
Although what is said on the plaque might speak loudly of silences and absences, or myths and lies, that is not the only story to be extracted from local edifices. If they are able to be satisfactorily reconstructed from archival and other sources, the 'hidden histories' of local memorials, Neumann argues, could be made to 'reflect and thus shed light on broader developments' in the nature and the politics of the remembrance and representation of particular pasts. ${ }^{10}$

Taking this approach in relation to the inscription plate on the cliff face at Botany Bay, and indeed to some other memorials that dot the local landscape, what if anything can the history of the memorial, rather than the history told on the memorial, tell us? What, for instance, can it tell us about Aboriginal presence in place, Aboriginal knowledge of past events, the use and abuse of that knowledge for colonial forms of historical remembrance, the nature of the link between Aboriginal and non-Aboriginal historymaking, and the nature of public memory more generally in nineteenth and twentieth century Australia? What might turn up if this particular exchange and others like it were examined in ways that go beyond what can be discerned from the memorial's tangible form? This is worth considering because it might be argued that concentrating one's analysis of the fragmentary evidence of Aboriginal testimony at the point at which the colonists' memorial project is realised - etched on brass or carved in stone to become a permanent sign on the landscape - contributes itself to obfuscating histories of Aboriginal presence, or of Aboriginal people's engagement with colonial commemoration and forms of history. By ending the story there, the old blackfella eyewitness remains forever hidden behind the engraved brass plate.

A close examination of the history of the story of the old blackfellow who supposedly contributed to the selection of the site for the inscription plate at Botany Bay in 1822 can tell us something about the shifting credence given not only to Aboriginal people's testimony, but also to what is often referred to as 'local knowledge', as sources for history and in efforts to settle disputed historical details. Whereas in the nineteenth century, this form of testimony was valued, by the early twentieth century its import was questioned by a new type of historian.

This can be seen most clearly in respect to the scrutiny given to the (supposed) testimony of the 'blackfellow, hoary with age' by the historian Charles $\mathrm{H}$ Bertie in the 1920s. By the time Bertie turns his attention to the history of Captain Cook at Botany Bay, the practice of history in Australia was becoming increasingly professionalised, and it was reflecting the developments in the discipline that had been taking place in England and Europe. ${ }^{11}$ As MacIntyre and Thomas note, in the nineteenth century the discipline of history 'underwent a scientific renovation in English universities. The discipline was effectively rebuilt around the systematic and technically rigorous examination of the documentary record' ${ }^{12}$ This model found its way to Australia, and was practised by a new class of historians in the opening decades of the twentieth century. In this context, old references to Aboriginal eyewitnesses to historic events were

10. Neumann 2000: 4.

11. See MacIntyre and Thomas 1995.

12. MacIntyre and Thomas 1995: 2. 
subjected to critique. In some quarters, these old and oral forms of historical remembrance were considered anathema to a new professional, positivist history. This is the tenor of Bertie's discussion of the reference to an 'Aboriginal eyewitness' to Captain Cook.

In April 1924, on the 154th anniversary of Captain Cook's landing at Botany Bay, Charles H Bertie challenged the veracity of both Dr Douglass' 1863 reference to the old blackfellow, and Joseph Carruthers' 1899 public recitation of Douglass' recollection. Bertie did so in an address he gave to the Royal Australian Historical Society, which was published the same year. ${ }^{13}$ Bertie questioned Douglass' and Carruthers' respective truthfulness, in part on the basis that he could find no reference to the old Aboriginal man in the relevant records (then newly discovered) of the Philosophical Society of Australasia, and in part on what he perceived as inaccuracies in Douglass' account. ${ }^{14}$

In his discussion, Bertie implied that the old blackfellow had been introduced into the story of the inscription plate only when Dr Douglass mentioned him 40 years after the event. From this time onwards, the 'old black man' had, in Bertie's view, become an erroneous element in the memorial's history. Bertie's personal quest was to correct this elaboration in the story of the plaque, which he identified as the product of Douglass' faulty memory, primarily because it had contributed to confusion about the exact point where Cook had first stepped ashore. The memory had messed up the history.

Indeed, the whole tenor of Bertie's paper was to rectify discrepancies which had crept into the histories told about Captain Cook at Botany Bay. 'It is my purpose in this paper', he wrote, 'to deal solely with the Endeavour's sojourn in Botany Bay, and to attempt to solve some of the questions which have arisen from that sojourn'. ${ }^{15}$ His project involved an attempt to sift what he deemed mistaken recollection from documented fact. In his quite lengthy study, in which he garners a diverse range of sources, including fragments of recollection from both Aboriginal and non-Aboriginal people, many of which he introduces in order to dismiss, Bertie attempts to peel away the accretions of 'local knowledge' which he believed had been responsible for introducing errors in the history of Captain Cook at Botany Bay. For this reason, his study provides a fascinating example of a mode of history, belonging to the early part of the twentieth century, which traverses the terrain between the increasingly valued 'positivist' approach to the writing of history, and more popular understandings of the past that typically owed much to claims of direct and personal knowledge about, or connection to, historical people, events and places. ${ }^{16}$

13. Bertie 1924

14. Minute book, 1821-1822, Philosophical Society of Australasia, Mitchell Library, FM3/99. It is certainly true that, in the various discussions of the brass plate recorded in the minutes of the Society, there is no mention of the 'black fellow'. Yet, this does not completely discount the possibility that some members of the Society went looking for and consulted with a local Aboriginal man. Rather, what this absence in the records tells us is that had some members of the Society undertaken such a quest, it was not included in the minutes of the Society's weekly meetings, held on Wednesday evenings in the respective houses of its members.

15. Bertie 1924: 234.

16. For a discussion of this shift in Australian history, see Thomas and MacIntyre 1995. For a discussion about how 'history' is interpreted as an enemy of 'memory', see Nora 1989. 
The publication of Bertie's 1924 treatise immediately generated another round of commentary and contestation about Captain Cook's history at Botany Bay, from Mr Carruthers and others. Once again, local knowledge and personal memories, including those of local Aboriginal people, were brought into the argument. ${ }^{17}$ For instance, in challenging one of Bertie's several claims based on a close reading of Cook's charts and journals, Carruthers' counters with some information that 'the old blacks of the neighbourhood (Billy Rowley and his mother being the oldest of our informants) told us'. ${ }^{18}$ Carruthers' overriding criticism of Bertie's historical method was that he lacked familiarity with the locality, which limited the extent to which he could accurately interpret the relevant documentary sources. Unlike Carruthers, he did not have access to local Aboriginal 'informants', who possessed intimate knowledge of the local landscape acquired over many years, and who had supposedly inherited knowledge from ancestors who had claimed to be there when Captain Cook came ashore. Without this local information, Carruthers implied, the historical knowledge to be gained from available documentary records, in this case Cook's charts and journals, would at best be inadequate, at worst in error.

In this respect, these debates about the history of Captain Cook at Botany Bay, played out in the pages of the journal of the Royal Australian Historical Society during the early part of the twentieth century, and commonly revolving around some piece of Aboriginal testimony, were as much a tussle over which types of historical evidence had credibility as they were about what actually happened in the past. In the 1920s, a debate about the value of Aboriginal (and indeed non-Aboriginal) oral testimony as historical source had begun, but it was not yet over, although Bertie's piece does mark a shift whereby local Aboriginal knowledge about historical events appears to begin to lose some of its standing, particularly among professional historians. This process unfolds in the opening decades of the twentieth century when the 'veil of silence' in Australian history about relations between Aboriginal and non-Aboriginal people descends, before Aboriginal people's memories begin to regain some cachet with the rise of oral history recording from the late 1960 s onwards. ${ }^{19}$

This general trend was evident in other forms of historical commemoration staged at Botany Bay. For instance, when the annual anniversary of Captain Cook's landing was faithfully commemorated each year at the spot, organised by the Trustees of Captain Cook's Landing Place Reserve, few references, if any, were made to Aboriginal people generally. More notably, neither were there references to the possible links between Aboriginal people then visibly living in the local area and those who had been there when Cook sailed through the heads. ${ }^{20}$ This was despite the fact that local Abo-

17. For a discussion of 'local knowledge' and historical memory, see Roberts 1995 and Schlunke 2005.

18. Carruthers 1925: 35.

19. See Stanner 1969: 18-29.

20. For copies of the programs for the annual commemoration of the landing of Captain Cook at Botany Bay, see Captain Cook's Landing Place Trust archives, Botany Bay National Park, Kurnell. The standard program included: the arrival of the official party by ferry, an inspection of a naval contingent, inspection of the Cook monument and landing rock, naval cadets marching to the flagstaff, speeches, breaking of the flag, firing of a salute, and planting of memorial trees. 
riginal people themselves from time to time publicly claimed a direct connection to the Indigenous people who were on the beach when Captain Cook arrived. ${ }^{21}$ The public evocation of a vital link between a remaining Aboriginal presence at Botany Bay and the time of Captain Cook's sojourn, which had been an element in colonial forms of commemoration in the nineteenth century, had by the middle part of the twentieth century become a thing of the past. Indeed, it seems that a divide had been erected between local Aboriginal forms of historical remembrance and what Chris Healy has called European social memory.

The schema that I have sketched by tracking the various references to, and arguments about, the local Aboriginal man who had reportedly assisted with the commemoration of Captain Cook and Banks in 1822 can be complemented and elaborated by reference to at least three more Aboriginal 'eyewitnesses' evoked in relation to other monument projects at Botany Bay across the nineteenth and twentieth centuries. An examination of the local histories of these three additional monuments contributes to the composition of a more textured picture of the uses of local Aboriginal people's historical testimony in the context of colonial commemoration. It reinforces the contours, already sketched, of the changing uses and meanings of Aboriginal testimony about historical events, particularly as they are deployed, or indeed dismissed, in new contexts of public memory and history. But, at the same time, these local histories of monuments provide glimpses of, and raise questions about, Aboriginal people's own uses of settler commemorative projects. Most importantly, it demonstrates the ways in which, by the middle of the twentieth century, when Aboriginal testimony is rarely sought in the effort to inscribe in permanent form colonial histories on the landscape, Aboriginal people use colonial commemorations as occasions to stake their own historical claim to place.

Two of the three additional public memorial projects discussed in this section are the marking of the burial sites of two white men who had died at Botany Bay while on voyages of 'discovery'. The first was a seaman (Forby Sutherland) on Captain Cook's expedition in 1770; the second a priest and naturalist (Pere Receveur) on Laperouse's

21. See, for instance, Long 1935: 13, for an account of story about Captain Cook's landing by a man known as Old Jimmy, told to Long at La Parouse on Botany Bay in the late nineteenth century; Cooper 1909: 1, for an account by members of the Timbery family living at La Perouse on Botany Bay of 'the story of their ancestors witnessing Captain Cook's

"Endeavour" making the coast under full sail at Botany Heads'; Interview, Gladys Ardler, NSW Bicentennial Oral History Project, National Library of Australia, 1987, ORAL TRC 2310 INT 71, in which she states that her mother's grandmother would 'tell us how they was on the beach at Kurnell on the ridge and Captain Cook came in and landed and they shot a couple of them on the ridge'. For a discussion of these and other references, see Nugent 2005. It is worth noting that some of the foundational members of the Captain Cook's Landing Place Trust were, in the early part of the twentieth century, interested in local Aboriginal accounts of Captain Cook's history, but it seems that this interest waned over time. See for instance, 'Notes of an interview between W. Houston Esq., one of the Trustees of Capt. Cook's Landing Place (Kurnell) and Mr - Longfield, at Kurnell on Sunday, the 22nd January 1905', Box 12, Item 141, Captain Cook's Landing Place Trust archives, Botany Bay National Park, Kurnell, which relates that an Aboriginal woman had learned from her uncle 'about the landing of Capt. Cook'. 
expedition in 1788 . The history of the respective origins of these two monuments spans a 100-year period: the memorial to the priest was first added to the landscape in 1824 (and replaced with an even sturdier structure five or so years later); the monument to Sutherland was first mooted in the 1920s and was finally realised in 1933. The third monument in this series marks another place where a British sailor first landed. It commemorates Captain Phillip's 'first' landing at Botany Bay in 1788; and was first proposed in 1950 before being finally unveiled in 1956.

\section{Enter Cruwee}

When the crew of Coquille, a French ship visiting Sydney in 1824, made a pilgrimage to Botany Bay to pay homage to Lapérouse's expedition, which had mysteriously disappeared after leaving the bay in 1788, they were keen to locate the burial place of a priest and naturalist, Pere Receveur. He had died and been buried on the north head of Botany Bay in February 1788, but his burial place had not been permanently marked. ${ }^{22}$ The men of the Coquille wished to mark its location on the landscape, which they did by engraving a nearby tree stump. ${ }^{23}$

To realise their commemorative project, the French pilgrims depended on 'local knowledge', because it was not clear from the extant records where the priest's remains lay. In ways that are very similar to the purported eyewitness account that had apparently contributed to the siting of the inscription plate to Cook and Banks on the opposite headland, a correspondent in the Sydney Morning Herald, Obed West, publicly claimed, decades after the French sailors' visit, that they had depended on information supplied by a local Aboriginal man named Cruwee for identification of the exact location of the burial site. ${ }^{24}$ After making inquiries about the tree stump engraved by the French sailors, West reported that he had been informed:

that a person named Richards took the party of French officers to the spot, and then got a blackfellow called Cruwee to point out the spot where the men [sic] of La Perouse's ships who died were buried. Cruwee pointed out the spot and it was [on] his information that the tree was marked so that the site should not be lost. ${ }^{25}$

Yet this account does not tally with the account in the expedition's journal published in the wake of their pilgrimage. That original account names as their guide a 'soldier who had been for a long time stationed at the spot', and it made no reference to the services of a local Aboriginal man in their quest for the burial site. ${ }^{26}$ The local Aboriginal man, Cruwee, had, it seems, been added to the story of the monument many years after its inauguration. Cruwee's appearance in later storytelling about the monument mirrors, in this respect, the introduction of the 'old blackfellow, hoary with age' in the story of the inscription plate.

22. For First Fleet references to the death and burial site, see White 1962: 126; The Voyage of Governor Phillip to Botany Bay 1970: 87; Tench 1996: 61-2; Collins 1974: 16.

23. See Selkirk 1918 and Nugent 2005. For the original published journal of the expedition, see Lesson 1838.

24. West 1882: 31 .

25. West 1882: 31 .

26. Selkirk 1918: 349 . 
Is it a mere coincidence that by the second half of the nineteenth century, a local Aboriginal person, cast in the role of possessor of knowledge about the location of a past event, is later added to the respective stories of monuments originally erected in the 1820s? If not a coincidence, what had made it necessary, or desirable, a generation or so later to introduce a local Aboriginal person as a source of information about the commemorated historical events? It should be noted that these events involved voyagers, predated British settlement, and therefore had not been. 'witnessed' by other Europeans apart from those on the expeditions themselves.

In both of these cases, the knowledge purportedly provided by an Aboriginal man was 'locational': they were the sources for knowledge about where precisely some event in the past had happened, including where someone had stepped ashore from a boat or where someone had been buried. They were not sources for what had happened, or for what they believed had happened. In this respect, Aboriginal testimony was being mobilised for a particularly popular form of history-making in the late nineteenth century, in which identifying where something happened precisely mattered. The concern was to meld history and geography, to map the first onto the second.

In this respect, the incorporation of local Aboriginal people into the stories told subsequently about colonial monuments belonging to an earlier generation might best be interpreted as part of the process by which the significance of old monuments is remade, or reactivated, within a new context of public memory, a generation or so after its inauguration. The figure of the Aboriginal eyewitness is introduced to help authenticate the historical veracity of a monument, and to reinforce its historical significance. The new stories told about the monuments reverse the process by which they might become obsolete, or increasingly obscure.

It is worth noting that the appeal to Aboriginal people's local knowledge to help with the project of fixing the European past in place occurs in a period marked by a belief in, and to some extent resignation about, the inevitable passing of Aboriginal people, and with them the knowledge they held. Some antiquarians of the period, as Tom Griffiths and Denis Byrne have noted, were primarily concerned with preserving knowledge about 'traditional' indigenous practices and society, although they did not always draw on living Aboriginal people as a source for this, preferring instead to accumulate evidence for 'old ways' through the collection of pre-contact material culture. ${ }^{27}$ But in the case of memorialisation of the European presence in the continent, the knowledge that Aboriginal people supposedly possessed, and which late nineteenthcentury monumental and antiquarian historians most valued, was not about Aboriginal people themselves, but about earlier Europeans, who the antiquarian historians understood as being their forefathers. Aboriginal people's knowledge was required in order for the colonists to preserve their own past.

But was it also the case that Aboriginal people themselves had taken on the mantle of the keeper of local knowledge about the early European past in the continent? Had this become a part of the ways in which they marked and claimed a relationship to what was now a colonised landscape?

27. Byrne 1996; Griffiths 1996. 


\section{Enter Sally Mettymong}

A reliance on local Aboriginal people's knowledge for identification in the present of the exact location of something from the past appears to have continued in the early part of the twentieth century. In disputes over the precise location of where someone was buried, or where something of historical import had happened, Aboriginal testimony was added to the range of sources that were consulted in a bid to clear up the matter, as was evident in the contours of the debate between Bertie and Carruthers discussed earlier. When, in the early 1920s, the Royal Australian Historical Society decided to erect a monument to Forby Sutherland, a seaman from Captain Cook's voyage who died and was buried on the southern shore of Botany Bay in 1770, who had acquired the status as 'first white man buried' on Australian soil, the remembered testimony of an old Aboriginal woman, Sally Mettymong, was summoned from the past to help identify where the man's remains lay, and thus the most appropriate spot for a monument to him.

Mettymong's testimony was introduced into the deliberations about where to place a monument to mark Sutherland's burial place by a Mr Laycock, then aged 78, who as a young boy had lived in the vicinity. According to Laycock, when he was about six years old, Mettymong would take him for walks along the beach, and when they passed the spot in question she would point and say ' white man buried there' ${ }^{28}$ These saunters took place in the 1850s, at which time Mettymong was apparently already 80 years old, which makes her a contemporary of the Indigenous people from the area when Cook sailed into the bay.

Although Mettymong's reported testimony was challenged in 1924 by Charles $\mathrm{H}$ Bertie in the same article discussed earlier, a monument to Forby Sutherland was nonetheless erected at the spot which her remembered testimony had identified, although not for another decade. ${ }^{29}$ Mettymong does not appear at all in the monument's inscription, which simply states that Forby Sutherland was buried 'near here'. Nevertheless, she is part of the story about the inauguration of this particular monument, which occurred in the early part of the twentieth century. ${ }^{30}$ Thus, in the process by which the Royal Australian Historical Society sought to preserve the memory of Forby Sutherland, even though some of its members questioned the veracity of her inherited memory, the old Aboriginal woman, Sally Mettymong, entered the records to become a remembered past presence in the same landscape. Her previous presence in the place was recorded, just like Cruwee's was in the case of the engraved tree stump marking the French priest's grave, in the context of public memory and the commemoration of the European past. Paradoxically, the history of her previous presence became attached to a monument marking, whether exactly or not, the grave of a seaman from Cook's voyage, whose burial was by this time widely interpreted as signaling British posses-

\footnotetext{
28. Appendix to Bertie 1924: 276.

29. Once again, the dispute about the precise location of the grave was fought out in the pages of the Journal of the Royal Australian Historical Society. See for instance, 'Report of a visit to Kurnell of the Committee of the Royal Australian Historical Society appointed to investigate the question of the burial place of Forby Sutherland', Appendix to Bertie 1924; MacDonald 1928.

30. For a longer discussion of this, see Nugent 2006: 86-93.
} 
sion of the territory. This is most clearly reflected in Barron Field's poem which claimed that Sutherland's 'Christian burial better did proclaim/ Possession, than the flag, in England's name'. ${ }^{31}$ The local history of the local monument, then, contains some evidence, admittedly not very visible, of Aboriginal presence at the site in the middle of the nineteenth century, which might or might not be continuous with that belonging to 1770 .

Perhaps more importantly, this scrap of reported testimony, which is summoned forth within the early twentieth-century context of public memory, can become the raw material for weaving a complementary story about the ways in which Aboriginal people claimed to possess local knowledge about the pasts of others. In such a corresponding and interrelated story, Sally Mettymong might become linked with Cruwee, with Billy Rowley and his mother, and with many others who appear from this time onwards saying things about what they know about Captain Cook, or Joseph Banks, or Lapérouse, or Pere Receveur, or Captain Phillip, or any other white man who stepped ashore at Botany Bay. ${ }^{32}$

\section{Enter Robert Timbery}

When it was decided in 1950 to erect a monument to mark where Captain Arthur Phillip had first stepped ashore at Botany Bay, Aboriginal 'eyewitness' testimony was not called upon as a source for identifying where precisely his landing had taken place. The task of locating the spot for the monument fell to Charles $\mathrm{H}$ Bertie, and his search was confined exclusively to the documentary records. ${ }^{33}$

But while those involved in a memorial project to commemorate physically an 'original' encounter no longer paid much heed to Aboriginal eyewitness testimony in their historical researches, the monument itself and the occasion of its inauguration were sources for stories about Aboriginal presence in place, both past and present. ${ }^{34}$ Unlike all the other monuments discussed so far, this one includes on its inscription reference to Indigenous people at the time that Phillip made his 'first' landing. At the insistence of some involved in the memorial project, a plaque containing information about Phillip's encounter with local Indigenous men was included on the monument. ${ }^{35}$ And while the memorialists did not go looking for the testimony of an Indigenous eyewitness to establish the proper location for the monument, in this case local Aboriginal people living in the vicinity of the monument at the time of its inauguration ascribed to themselves something of this role.

The monument was unveiled on 18 January 1956 at three o' clock, exactly 168 years after the event that it marked. The ceremony included predictable elements: the performance of a historical re-enactment of Phillip arriving on shore in a long boat and speeches by dignitaries that served as history lessons. Many local Aboriginal people

31. Barron Field, 'On visiting the spot where Captain Cook and Sir Joseph Banks first landed at Botany Bay', Sydney Gazette, 22 March 1822, cited in Healy 1997: 42-43.

32. The author is currently engaged in a research project examining Aboriginal people's historical remembrance in south-eastern Australia in the nineteenth and twentieth centuries tentatively titled 'Blackfella Historians', which draws on these types of Aboriginal testimony.

33. Bertie 1952: 107-26.

34. For a longer discussion of this monument, see Nugent 2005: 132-136.

35. See Nugent 2005: 133. 
attended the unveiling. One newspaper report noted that there were 'about 800 sightseers, many of them from the La Perouse reserve'. ${ }^{36}$ One had come with a gift in hand. Robert Timbery explained to an official that he had 'made this boomerang myself for the Governor. Souvenir for him. Show we're still friendly' ${ }^{37}$ His reference to 'show we're still friendly' indicated that this relationship had its origins in the very first time the two groups came into contact, when the local Indigenous people had shown Phillip where to find water. By this exchange, Timbery reminded the Governor of his relationship, as a representative of the government, with the Aboriginal people on whose behalf Timbery spoke. Timbery was invited to sit on the dais along with the official guests, and after the formal program was over he was allowed to present the boomerang to the Governor.

The improvised exchange between Timbery and the Governor has been depicted as symbolically re-enacting the relations between Phillip and local Aborigines that had occurred during the actual encounter at the site in January 1788. That it was in spirit, at least, an authentic representation of the original encounter was underscored by repeated reference to two powerful links connecting the present-day participants with the past. The recipient of the boomerang, the governor of New South Wales, was described as the 33rd in direct line from Governor Phillip to hold that office. Robert Timbery, the maker and presenter of the boomerang, described himself as the 'oldest direct descendant at Yarra Bay of the tribe which was there when Captain Phillip arrived' $^{38}$

This claimed continuous descent from those 'natives' who had witnessed, encountered and had exchanges with Phillip in 1788 belonged to a local tradition, probably at least a hundred years old by the 1950s, whereby local Aboriginal people had claimed to be the direct descendents of those on the shore when either Captain Cook (1770), or Lapérouse (1788), or Captain Phillip (1788) arrived in the bay. ${ }^{39}$ It was this local Aboriginal tradition to claim the status as eyewitnesses, or at least to be the direct descendants of eyewitnesses, which had also been in evidence in the mid-nineteenth century, when the figure of the Aboriginal eyewitness was incorporated into the stories told about monuments that had been added to the landscape decades earlier. This tradition had endured for decades so that even though mid-twentieth-century historians and memorialists had lost faith in Aboriginal testimony as an historical source, their memorial project nonetheless provided an occasion for local Aboriginal people to make public their claims to fulfilling this very role.

\section{Conclusion}

When Chris Healy was undertaking his study into black and white Australian social memory, he was working in a period when black and white histories were primarily understood as oppositional to each other, the former talking back to the latter in order to expose and challenge the silences and misrepresentations that had long characterised

\footnotetext{
36. Sydney Morning Herald, 19 January 1956: 2.

37. Sydney Morning Herald, 19 January 1956: 2.

38. Sydney Moming Herald, 19 January 1956: 2. See also Randwick Municipal Council, Mayoral Minute, 17 January 1956.

39. See footnote 21 for some examples.
} 
it. In this context, evidence of exchanges between Indigenous people and 'white' historians, antiquarians and monument-makers were interpreted negatively, as abuses of Aboriginal testimony, for instance, or as missed opportunities for the production of two-sided, dialogical histories. ${ }^{40}$ In this paper I have sketched an approach in which local histories of colonial memorial projects can tell us more about, and more than, the 'abuse' and 'misuse' of Aboriginal people's historical memory by settler Australians. These local histories of colonial memorials provide windows onto the shifting uses of, and esteem given to, Aboriginal testimony in colonial forms of history. As the contexts of public memory and history changes, so does the assessment and valorisation of Aboriginal historical testimony. Moreover, a (purported) piece of Aboriginal historical testimony is sometimes at the centre of contestations over historical evidence, and historical method, among 'settler' historians.

It is now the case that we know much about how it was that Aboriginal people dropped from view in Australian history, or were not a visible presence on the physical edifices erected to what was popularly understood as a heroic and pioneering past. Yet, there is still much to learn about how Aboriginal people themselves variously engaged with colonial forms of commemoration, and with colonial historical narratives, throughout the nineteenth century and the first half of the twentieth century. In this paper, I have suggested that the figure of the Aboriginal eyewitness is one means by which to investigate these practices, noting however that the figure should not be taken as given. Rather, my point is that the Aboriginal eyewitness as he or she appears in the archive can sometimes be read as evidence of Aboriginal people's engagement with colonial historical practices as well as a product of colonial historical practices. In this way, the 'eyewitness' can tell us something about Aboriginal as well as non-Aboriginal forms of history-making in the colonial period, and the nature of their relationship to each other.

\section{Acknowledgement}

The author acknowledges the generous assistance of the National Museum of Australia through its National Museum Research Fellowship Program.

\section{References}

Bertie, Charles H 1924, 'Captain Cook and Botany Bay', The Royal Australian Historical Society Journal and Proceedings 10(5): 233-278.

- 1952, 'Captain Arthur Phillip's first landing place in Botany Bay', The Royal Australian Historical Society Journal and Proceedings 38(3): 107-26.

Bulbeck, Chilla 1991, 'Aborigines, memorials and the history of the frontier', in John Rickard and Peter Spearitt (eds), Packaging the past? Public histories, Melbourne University Press, Melbourne: 168-178.

Byrne, Denis 1996, 'Deep nation: Australia's acquisition of an indigenous past', Aboriginal History 20: 82-106.

40. This was the argument that Healy advanced in relation to the blackfellow's contribution to the plaque commemorating Cook and Banks at Botany Bay in 1822. 
Carruthers, Joseph 1899, 'Speech', in 'Kumell' the landing place of Captain Cook 1770 Official Proceedings 6 May 1899, commemorative booklet, copy held in Captain Cook's Landing Place Trust archives, Botany Bay National Park, Kurnell, NSW.

- 1925, 'Captain Cook and Botany Bay: comments on the paper by Mr. C. H. Bertie', The Royal Australian Historical Society Journal and Proceedings 11: 32-38.

Collins, David 1974 [1798], An account of the English colony in New South Wales, London, reprinted A. H. \& A. W. Reed in association with the Royal Australian Historical Society, Sydney.

Cooper, DM 1909, Randwick: 1859-1909, Randwick Municipal Council, Sydney.

Griffiths, Tom 1987, 'Past silences: Aborigines and convicts in our history-making', Australian Cultural History 6: 18-32.

- 1996, Hunters and collectors: the antiquarian imagination in Australia, Cambridge University Press, Melbourne.

Healy, Chris 1997, From the ruins of colonialism: history as social memory, Cambridge University Press, Melbourne.

Lesson, Rene Primevere 1838, Voyage autour du monde sur la Corvette la Coquille, $\mathrm{P}$. Pourrat Fréres, Paris.

Long, Retta 1935, Providential channels, Australian Inland Mission, Sydney.

MacDonald, WA 1928, 'Forby Sutherland's grave at Kurnell', Royal Australian Historical Society Journal and Proceedings 14: 281-298.

MacIntyre, Stuart and Julian Thomas 1995, 'Introduction', in S MacIntyre and J Thomas (eds), The discovery of Australian history 1890-1939, Melbourne University Press, Melbourne.

Neumann, Klaus 2000, Shifting memories: the Nazi past in the new Germany, Michigan University Press, Ann Arbor.

Nora, Pierre 1989, 'Between memory and history: Les lieux de memoire', Representations 26 (Spring): 7-24.

Nugent, Maria 2005, Botany Bay: where histories meet, Allen \& Unwin, Sydney.

- 2006, 'Contextual history of Botany Bay National Park, Kurnell Section', prepared for the Department of Environment and Conservation (NSW), Sydney.

Roberts, David 1995, 'Bells Falls massacre and Bathurst's history of violence: local tradition and Australian historiography', Australian Historical Studies 26(105): 61533.

Scates, Bruce and Rae Frances 1989, 'Honouring the Aboriginal dead', Arena 86: 72-80.

Schlunke, Katrina 2005, Bluff Rock: autobiography of a massacre, Curtin University Press, Perth.

Selkirk, Henry 1918, 'La Perouse and the French monuments at Botany Bay', The Royal Australian Historical Society Journal and Proceedings XIV: 329-61.

Stanner, WEH 1969, 'The great Australian silence', in After the Dreaming: The Boyer Lectures 1968, The Australian Broadcasting Commission, Sydney.

Stockdale, John (compiler) 1970 [1789], The Voyage of Governor Phillip to Botany Bay London, reprinted Angus and Robertson in association with the Royal Australian Historical Society, Sydney. 
Tench, Watkin 1996, 1788: comprising a narrative of the expedition to Botany Bay and a complete account of the settlement at Port Jackson, Tim Flannery (ed), Text Publishing, Melbourne.

West, Obed 1882, Old and new Sydney, reprinted from the Sydney Morning Herald, Edward Hordern and Sons, Sydney.

White, John 1962 [1790], Journal of a voyage to New South Wales, J Dabrett, London, reprinted Angus and Robertson in association with the Royal Australian Historical Society, Sydney. 